\title{
Consumption of Jelly Combination of Salacea Seed (Salacca zalacca) and Moringa Leaves Flour (Moringa oleifera) on Hemoglobin level in Female Adolescents with Moderate Anemia
}

\author{
Poppy Wijayanti'), Yulia Lanti Retno Dewi²), Dono Indarto3) \\ ${ }^{1)}$ Masters Program in Public Health, Universitas Sebelas Maret \\ 2)Department of Nutrition, Faculty of Medicine, Universitas Sebelas Maret \\ 3)Biomedical Laboratory, Faculty of Medicine, Universitas Sebelas Maret
}

\section{ABSTRACT}

Background: Adolescent girls are at risk for iron-deficiency anemia. Various food fortifications have been developed to reduce the incidence of anemia. This study aimed to investigate the effect of consumption of jelly combined with salacca pondoh seed flour and Moringa leaf flour on hemoglobin levels in adolescent girls with moderate anemia.

Subjects and Method: The Randomized Control Trial study was conducted in high schools, Banyuwangi, East Java, from August to September 2020. A total of 75 high school girls with moderate anemia were randomly divided into three groups with 25 people in each group, namely: (1) Control group (C) get a combination of $100 \mathrm{~g}$ plain jelly, and iron tablets; (2) Treatment group 1 (T1) received $100 \mathrm{~g}$ of jelly combined with $14.9 \mathrm{~g}$ of salacca pondoh seed flour and $5.7 \mathrm{~g}$ of Moringa leaf flour; and (3) Treatment group 2 (T2) received $100 \mathrm{~g}$ of jelly which had been combined with $7.5 \mathrm{~g}$ of salacca pondoh seed flour and $3 \mathrm{~g}$ of Moringa leaf flour. The treatment was given twice per week for 8 weeks. The dependent variable is hemoglobin level. The independent variable was administering a combination of jelly with salacca seed flour and Moringa leaf flour. Hemoglobin data was taken by laboratory examination on days 30 and 60. Data were analyzed using One Way Anova.

Results: After the intervention, the average hemoglobin levels in the three groups increased during the 30th day of observation: $\mathrm{C}(\mathrm{Mean}=14.68 ; \mathrm{SD}=0.75)$, $\mathrm{T} 1(\mathrm{Mean}=15.5 \mathrm{O} ; \mathrm{SD}=0.90)$, and T2 $($ Mean= 14.47; $\mathrm{SD}=0.79)$. There was an average increase in hemoglobin levels in the three groups during the $60^{\text {th }}$ day of observation, namely: $\mathrm{C}(\mathrm{Mean}=14.96 ; \mathrm{SD}=0.81)$, T1 $(\mathrm{Mean}=15.20$; $\mathrm{SD}=0.78)$, and T2 $(\mathrm{Mean}=14.96 ; \mathrm{SD}=0.69)$. On the $30^{\text {th }}$ and $60^{\text {th }}$ day observations, the difference in mean between the three groups was not statistically significant $(p=0.412)$ and $(p=0.703)$.

Conclusion: The administration of jelly combined with salacca pondoh seed flour and Moringa leaves is effective compared to plain jelly with iron tablets in increasing Hb levels.

Keywords: combination jelly, salacca seeds, moringa leaves, hemoglobin, anemia, young women

\section{Correspondence:}

Poppy Wijayanti. Masters Program in Public Health, Universitas Sebelas Maret. Jl. Ir. Sutami 36A, Surakarta 57126, Central Java. Email: popzalao4@gmail.com. Mobile: +6285235925411.

\section{Cite this as:}

Wijayanti P, Dewi YLR, Indarto D (2021). Consumption of Jelly Combination of Salacca Seed (Salacca zalacca) and Moringa leaves Flour (Moringa oleifera) on Hemoglobin level in Female Adolescents with Moderate Anemia. Indones J Med. 06(03): 307-314. https://doi.org/10.26911/theijmed.2021.06.03.08.

cC (i) (2) Indonesian Journal of Medicine is licensed under a Creative Commons

EY NC SA Attribution-Non Commercial-Share Alike 4.0 International License.

\section{BACKGROUND}

Anemia is a nutritional problem that occurs worldwide, with a prevalence of $27 \%$ (1.93 billion people) in 2013. Half a billion people with anemia are women of childbearing age (WUS), and iron deficiency is the main cause of anemia (Nicholas and Kasebaum, 2016; WHO, 2015). Anemia during adole- 
scence is a nutritional problem and negatively affects growth and cognitive, academic achievement, and serious impact during the reproductive years. Anemia in pregnant adolescents increases maternal morbidity and mortality and increases risks to the fetus, such as low birth weight and premature birth (Masthalina et al., 2015). Based on Riskesdas data in 2013, the prevalence of anemia in Indonesia's 15-24year age group was $18.4 \%(10.4 \%$ in women and $8 \%$ in men) (Ministry of Health, 2014a).

Clinical signs of iron deficiency anemia can be mild to severe, such as pale skin, easy fatigue, vertigo, fainting, shortness of breath, headache, tachycardia, and a systolic heart murmur (Aldallal, 2016). The diagnosis of anemia is based on clinical signs, physical examination and laboratory tests (Ganz, 2013). Normal hemoglobin levels are $13 \mathrm{mg} / \mathrm{L}$ for men and $12 \mathrm{mg} / \mathrm{L}$ for women, while children and pregnant women are $11 \mathrm{mg} / \mathrm{L}$ (Clarke, 2014).

To deal with the problem of anemia, the Indonesian government has carried out an anemia prevention program with iron supplementation in the form of blood-added tablets containing $60 \mathrm{mg}$ of iron and 400 $\mathrm{g}$ of folic acid. The targets for giving this blood-added tablet are young women and pregnant women. Pregnant women are given a minimum of 90 blood-added tablets during pregnancy, while young women are given once a day during menstruation and once a week for 16 weeks (Ministry of Health, 2013).

Pondoh salacca is the largest agricultural product in the Sleman Regency area. Local residents have used it for home industries by using fruit flesh, skin, and seeds of salacca. Salacca coffee beans were the first processed to be introduced to the wider community and were popular because they did not contain caffeine (Wer- dyani et al., 2017). Salacca seed flour has a high Fe content and Moringa leaf flour, which has a high Fe content, so the authors are interested in making food fortification from a combination of salacca seed flour and Moringa leaf flour. This study aimed to investigate the effect of consumption combined with salacca pondoh seed flour and Moringa leaf flour on hemoglobin levels in adolescent girls with moderate anemia.

\section{SUBJECTS AND METHOD}

\section{Study Design}

This study is a Randomized Control trial (RCT) conducted in SMA, Banyuwangi city, East Java, from August to September 2020.

\section{Population dan Sample}

The sample in this study was 75 adolescent girls with moderate anemia studying in high school, selected and randomly divided into three groups with 25 people allocated to each group. The control group (C) received a combination of $100 \mathrm{~g}$ plain jelly and iron tablets. Treatment group 1 (T1) got $100 \mathrm{~g}$ of jelly which had been combined with 14.9 grams of pondoh salacca seed flour and 5.7 grams of Moringa leaf flour. Treatment group 2 (T2) got 100 g of jelly which had been combined with 7.5 grams of pondoh salacca seed flour and 3 grams of Moringa leaf flour. The treatment was given twice per week for 8 weeks.

The selected samples met the inclusion criteria, namely: (1) Young women aged 16-18 years; and (2) There is moderate anemia $(\mathrm{Hb}$ level $=8.0-10.9 \mathrm{~g} / \mathrm{dL})$. Adolescent girls who were not selected if they met the exclusion criteria were: (1) Menstruating during screening; (2) Have a history of diseases that affect $\mathrm{Hb}$ (TBC, DHF, Malaria, helminthiasis); (3) taking dietary supplements of vitamin $\mathrm{C}$ and iron supplements; and (4) Have a food allergy made from flour. 


\section{Study Variables}

The dependent variable is hemoglobin level. The independent variable is administering a combination of jelly with salacca seed flour and Moringa leaf flour.

\section{Operational Definition of Variables}

Anemia. The diagnosis of anemia is based on physical and laboratory examinations. Physical examination is performed to find signs of organ involvement and assess the severity of the patient's anemia.

Hb levels. Moderate anemia in adolescent girls is 8.0-10.9 g/dL. Adolescent girls aged 15-19 years are normal $12 \mathrm{~g} / \mathrm{dL}$. Taken using a spectrophotometer using the cyanmethemoglobin method.

Combination Jelly was made in combinations with different amounts, namely: (1) $14.9 \mathrm{~g}$ of salacca seed flour and $5.7 \mathrm{~g}$ of moringa flour for $\mathrm{P} 1$; (2) $7.5 \mathrm{~g}$ of salacca seed flour and $3 \mathrm{~g}$ of Moringa flour for T2; and the control group was given jelly without the combination of flour and Fe tablets.

\section{Data Analysis}

Sample characteristics are presented with univariate in mean, $\mathrm{SD}$, minimum, and maximum. Bivariate analysis was carried out to test the difference in the mean between groups using One Way Anova to determine the comparison of the mean hemoglobin levels on the initial day of the study, the $30^{\text {th }}$ and $60^{\text {th }}$ in each group.

\section{Research Ethics}

This study was conducted based on research ethics, namely, confidentiality, anonymity, informed consent, and ethical research. Research ethics were obtained from the Health Research Ethics Committee at the Chakra Brahmanda Lentera Institute with No.016/27/XI/EC/KEPK/-Lemb.Candle/2020.

\section{RESULTS}

\section{A. Univariate Analysis}

Based on Table 1 characteristics of the sample, the mean age is 16.76 years with an SD of 0.77 , a minimum age of 16 years, and a maximum of 18 years. Height has a mean of 161.56 years with SD 7.17, a minimum height of $156 \mathrm{~cm}$, and a maximum of 175 $\mathrm{cm}$. Bodyweight has a mean of $53.48 \mathrm{~kg}$ with an SD of 9.21 with a minimum weight of $40 \mathrm{~kg}$ and a maximum of $70 \mathrm{~kg}$. Hb levels have a mean of $9.02 \mathrm{~g} / \mathrm{dL}$ with SD 0.14 , minimum $\mathrm{Hb} 8.70$, and a maximum of 9.30.

Based on Table 2, the age of the research subject was 40\%, 16 years old, 17 years old $36 \%$, and 18 years old $24 \%$. The father's regional minimum wage family income is $54 \%$ and for the mother $68 \%$. Research subjects do not have food allergies to seafood, eggs, and flour. The research subjects did not have diseases that interfere with iron absorption, namely DHF, intestinal worms, typhoid, and malaria.

Table 3 showed the results of the combined jelly test. The SNI (Indonesian National Standard) test was carried out to see the safety of consumption of combined jelly using the quality requirements of jelly, namely SNI 01-0222-1987 testing. The test results showed that the combination jelly meets the requirements for physical, chemical, and microbiological characteristics. The content in the combination jelly is $8.49 \mathrm{mg}$ in one dose and $5.14 \mathrm{mg}$ in half the dose in 100 grams of combination jelly.

Table 4 showed an effect of combined jelly consumption on $\mathrm{Hb}$ levels of moderately anemic adolescent girls after the intervention.

The average hemoglobin level in the three groups increased during the 3oth day of observation, namely the control group (Mean=14.68; $\mathrm{SD}=0.75)$, treatment group 1 (Mean $=15.50 ; \mathrm{SD}=0.90)$, and treatment group $2($ Mean $=14.47 ; \mathrm{SD}=0.79)$, but the difference in mean between the three groups was not statistically significant $(\mathrm{p}=0.703)$. 
Wijayanti et al./ Jelly Combination of Salacca Seed and Moringa Leaves Flour on Hemoglobin

Table 1. Characteristics of the sample (numeric data)

\begin{tabular}{lcccc}
\hline \multicolumn{1}{c}{ Variables } & Mean & SD & Min & Max \\
\hline Age (year) & 16.76 & 0.77 & 16 & 18 \\
Height $(\mathrm{cm})$ & 161.56 & 7.17 & 156 & 175 \\
Weight $(\mathrm{kg})$ & 53.48 & 9.21 & 40 & 70 \\
BMI $\left(\mathrm{kg} / \mathrm{m}^{2}\right)$ & 20.24 & 2.22 & 16.20 & 23.50 \\
Hb level $(\mathrm{gr} / \mathrm{dL})$ & 9.021 & 0.14 & 8.70 & 9.30 \\
\hline
\end{tabular}

Table 2. Characteristics of the sample (categorical data)

\begin{tabular}{llcc}
\hline \multicolumn{1}{c}{ Characteristics } & \multicolumn{1}{c}{ Categories } & Frequency & Percentage \\
\hline Age (year) & 16 & 30 & $40 \%$ \\
& 17 & 27 & $36 \%$ \\
Family Income & 18 & 18 & $24 \%$ \\
Father & & 41 & $54 \%$ \\
Mother & $<$ minimum wage & $46 \%$ \\
& $\geq$ minimum wage & 54 & $68 \%$ \\
Illness & $<$ minimum wage & 51 & $32 \%$ \\
& $\geq$ minimum wage & 24 & $0 \%$ \\
Allergy & TB, worms, DHF, typhoid, & 0 & $0 \%$ \\
\hline
\end{tabular}

Table 3. Combination jelly test results

\begin{tabular}{lcccc}
\hline Parameters & $\begin{array}{c}\text { Minimum requirements } \\
\text { of supplemental feeding }\end{array}$ & Treatment 1 & $\begin{array}{c}\text { Treatment } \\
\mathbf{2}\end{array}$ & Test method \\
\hline Energy (kcal) & 300 & 69.26 & 29.7 & Calculation \\
Carbohydrates(g) & 40 & 13.8 & 6.55 & Luff school \\
Protein (g) & 6 & 2.21 & 0.82 & Kjeldahl \\
Fat (g) & 13 & 0.58 & 0.02 & Weibull \\
Fe (mg) & - & 8.49 & 5.14 & Colorimetry \\
Vitamin C & - & Negative & Negative & HPLC \\
& & & & (High-performance \\
& & & & liquid chromatography) \\
\hline
\end{tabular}

Similarly, there was an increase in the average hemoglobin level in the three groups during the $60^{\text {th }}$ day of observation, namely the control group (Mean=14.96; $\mathrm{SD}=0.81$ ), treatment group $1(\mathrm{Mean}=15.20 ; \mathrm{SD}=0.78)$, and treatment group 2 (Mean= 14.96; $\mathrm{SD}=$ o.69), but the difference in mean between the three groups was not statistically significant $(\mathrm{p}=0.412)$.

\section{DISCUSSION}

This study used a combination jelly as a portion of additional food for anemic adolescent girls by analyzing the status of hemo- globin levels and erythrocyte index after administration for 30 and 60 days. Before the combination jelly was chosen, the fortification used was cookies. Still, the right formulation was not found even though it had been tried with various compositions and oven temperature settings (data not shown).

This study refers to the study of Sani (2014), which uses jelly as an intervention medium. In this study, Fe was in the form of microcapsules containing ferrous sulfate (FeSO4) and added to the jelly. 
Wijayanti et al./ Jelly Combination of Salacca Seed and Moringa Leaves Flour on Hemoglobin

Table 4. Effect of consumption of combined jelly on Hb levels

\begin{tabular}{lccc}
\hline \multicolumn{1}{c}{ Group } & Mean & SD & p \\
\hline Hb Pretest (gr/dL) & & & \\
Control & 9.01 & 0.13 & 0.859 \\
Treatment 1 & 9.03 & 0.15 & \\
Treatment 2 & 9.03 & 0.15 & \\
Hb day 30 (gr/dL) & & & \\
Control & 14.68 & 0.75 & 0.703 \\
Treatment 1 & 15.50 & 0.90 & \\
Treatment 2 & 14.47 & 0.79 & \\
Hb day 6o (gr/dL) & & & \\
Control & 14.96 & 0.81 & \\
Treatment 1 & 15.20 & 0.78 & \\
Treatment 2 & 14.96 & 0.69 & \\
\hline
\end{tabular}

This study refers to the study of Sani (2014), which uses jelly as an intervention medium. In this study, Fe was in the form of microcapsules containing ferrous sulfate (Fe$\mathrm{SO}_{4}$ ) and added to the jelly. For the use of salacca seed flour, according to Nugraheni's research (2020), using salacca seed flour as a mixture. Jelly has a lack of minimum vitamin $\mathrm{C}$ content of $2 \mathrm{mg}$.

Combined jelly is a combination of salacca seed flour and moringa leaf flour plus orange juice. Where before, the research was expected to have vitamin $\mathrm{C}$ content, but the results of the Unair pharmacy laboratory were negative for vitamin $\mathrm{C}$ content. Due to the long boiling process, the combination jelly lost its vitamin $\mathrm{C}$ content. According to SNI, as a new product used in this study, the combined jelly has been tested for feasibility. The combination jelly contains no cyclamate sweeteners and saccharin sweeteners.

Iron is an important element in the body. Iron acts as a component of enzymes and is involved in various metabolic processes. The total amount of iron in a person weighing $70 \mathrm{~kg}$ can reach $3.5 \mathrm{~g}$ or $50 \mathrm{mg} / \mathrm{kg}$. Approximately $65 \%$ of iron $(2,300 \mathrm{mg})$ is stored in erythrocytes, $10 \%$ (350 $\mathrm{mg}$ ) is found in myoglobulins and other tissues (enzymes and cytochromes), $200 \mathrm{mg}$ is stored in the liver, $500 \mathrm{mg}$ is in the reticuloendothelial sys- tem (RES), and $150 \mathrm{mg}$ is stored in the liver and bone marrow. The daily requirement of iron in the body is $20-30 \mathrm{mg} /$ day used for the erythropoiesis process. The body absorbs iron from food under normal conditions of 1$2 \mathrm{mg} /$ day (Munoz et al., 2005)

The iron absorption process occurs in the duodenum and proximal jejunum, which is influenced by the chemical form of iron, organic acids, and gastric acid secretion (Mackenzie and Garrick, 2005). The bioavailability of heme and non-heme iron is different. The absorption of non-heme iron requires a long process. This happens because the available non-heme iron is still in oxidized form $\left(\mathrm{Fe}^{3}\right)$, so a reduction process is needed to form $\mathrm{Fe}^{2+}$. When heme and nonheme iron are consumed together, heme iron will be more easily absorbed, estimated to be 15-30\% more than non-heme iron (Gupta et al., 2014). The process of reducing non-heme iron $\mathrm{Fe}^{3+}$ to $\mathrm{Fe}^{2+}$ occurs before it is transported across the intestinal epithelium, using the enzyme ferrireductase with the help of coenzyme vitamin C (Munoz et al., 2011).

This study applied Susanti's research (2018) which stated that giving salacca seed flour can increase $\mathrm{Hb}$ levels in anemic rats. Combined jelly can increase $\mathrm{Hb}$ levels in anemic adolescent girls after 60 days of the administration, with a significant increase, so 
that female adolescents are not anemic. Through this study, researchers concluded that the consumption of combination jelly could increase the $\mathrm{Hb}$ levels of moderately anemic adolescent girls and consume ordinary jelly with the addition of Fe tablets.

This study also has research limitations, namely, physical activity and consumption of foods containing Fe inhibitors were not controlled during the study. These two factors affected the absorption of Fe. So, to prevent helminthiasis, which can affect the Fe absorption process, only worm medicine is given in the form of combating tablets, the count and type of leukocytes are not checked at the beginning of the study, so it is not known whether the research subject has an infection or not which will affect the Hb level.

Further research is needed to control confounding factors, such as physical activity, consumption of foods containing Fe inhibitors, helminthiasis, menstruation, and infection/inflammation. In addition, it is necessary to test other hematological indicators with a minimum of three repetitions.

The implications of the findings of salacca seed flour and moringa leaf flour can be used as an alternative food ingredient or as an additional food mixture with local wisdom to overcome anemia in the community. Combination jelly is used as a model for supplemental food or complementary supplementation of Fe tablets for anemic patients, especially adolescent girls.

\section{AUTHORS' CONTRIBUTION}

Poppy Wijayanti is the main researcher who plays a role in data collection, research, formulation of research articles, and data processing. Yulia Lanti played a role in formulating the background, framework, research discussions, and methodology. Dono Indarto helped formulate the theory review and research discussion.

\section{FUNDING AND SPONSORSHIP}

This study is self-funded.

\section{CONFLICT OF INTEREST}

There is no conflict of interest in this study.

\section{ACKNOWLEDGMENT}

The authors would like to thank all the subjects who have been willing to work together to become respondents in this study.

\section{REFERENCES}

Aldalal S (2016). Iron deficiency anaemia: a short review. J. Cancer Res. Immunooncol. 2:106.

Bakta IM (2017). Pendekatan diagnosis dan terapi pada penderita anemia. Bali Health Journal. 1.1 36-48.

Amalia A, Tjiptaningrum, Agustyas (2016). Diagnosis dan tatalaksana anemia defisiensi besi. Jurnal Majority. 5.5: 166169.

Atanassova BD, Tzatchev KN (2008). Ascorbic acid important for iron metabolism. Folia Med (Plovdiv). 50(4):11-6. PMID: 19209525.

Briawan D, Sulaeman A, Syamsir E, Herawati D. (2013). Efikasi fortifikasi cookies ubi jalar untuk perbaikan status anemia siswi sekolah. Majalah Kedokteran Bandung. 45 (4): 206-212. DOI: 10.15395/mkb.v45n4.166.

Ganz T (2013). Systemic iron homeostasis. Physiol. Rev. 93(4): 1721-1741. DOI: 10.1152/physrev.0ooo8.2013.

Fadliyah (2018). Pengaruh dosis dan lama pemberian coklat cookies kelor terhadap kadar hemoglobin dan lingkar lengan atas remaja putri anemia dan kurang gizi. Tesis. Pascasarjana. Universitas Sebelas Maret. Surakarta.

Fitri YP, Briawan D, Tanziha I, Amalia L (2015). Iron supplementation compliance and its influences on anemia prevalence among pregnant women in 
Wijayanti et al./ Jelly Combination of Salacca Seed and Moringa Leaves Flour on Hemoglobin

Tangerang. Jurnal Gizi dan Pangan. 10(3): 171-178. DOI: https://doi.org/10.25182/jgp.2015.10.3.\%25p.

García Y, Carrillo O, Cárdenas R, Díaz CJ (2017). Advantages of the supplementation with both a protein and heme hydrolyzate and ionic iron during iron deficiency anemia. J. Food Nutr. Res. 5 (1): 37-47. DOI: https://doi.org/10.25182/jgp.2015.10.3.\%25p.

Gunadi D, Lubis B, Rosdiana N (2016). Terapi dan suplementasi besi pada anak. Sari Pediatri. 11(3): 207-11.

LoCicero R (2018). U.S. National library of medicine medline plus. Anaemia. National Institute of Health.

Kassebaum NJ (2016). The global burden ofanemia. Hematology/OncologyClinic s. 3O(2): 247-308. DOI: 10.1016/j.hoc.2015.11.002.

Mackenzie B, Garrick MD (2005). Iron Imports. II. Iron uptake at the apical membrane in the intestine. Am. J. Physiol. Gastrointest. 289(6): G981-G986.

Doi: 10.1152/ajpgi.00363.2005

Masthalina H (2015). Pola konsumsi (faktor inhibitor dan enhancer Fe) terhadap status anemia remaja putri on anemia status of adolescent girls). KEMAS. 11 (1):80-86. DOI: https://doi.org/10.15294/kemas. v11i1.3516.

Mousa SMO, Saleh SM, Higazi AMM, Ali HAA (2016). Iron deficiency and iron deficiency anemia in adolescent girls in rural upper Egypt. Int. blood res. rev.16. DOI: $10.9734 / \mathrm{IBRR} / 2016 / 25826$

Muñoz M, García-Erce JA, Remacha ÁF (2011). Disorders of iron metabolism. part 1: molecular-basis-of-iron-homeostasis. J. Clin. Pathol. 64(4): 281-286. DOI: $\underline{10.1136 / j \mathrm{jp} .2010 .079046}$

Nugraheni Martha (2020). Pengaruh dosis dan lama pemberian jeli biji salacca terhadap status hematologi dan status gizi pada remaja putri anemia. Tesis. Universitas Sebelas Maret. Surakarta Rusdi PHN, Oenzil F, Chundrayetti E (2018). Pengaruh pemberian jus jambu biji merah (Psidium Guajava. L) terhadap kadar hemoglobin dan ferritin serum penderita anemia remaja putri. Jurnal Kesehatan Andalas. 7(1):74-79. DOI:https://doi.org/10.25077/jka.v7i1.782.

Smith RD, Prévot MS, Fagan RD, Trudel S, Berlinguette CP (2013). Water oxidation catalysis: electrocatalytic response to metal stoichiometry in amor-phous metal oxide films containing iron, cobalt, and nickel. J. Am. Chem. Soc. 135(31): 11580-11586. DOI.org/10.1021/ja403102j.

Seonglim L, Jaehye S, Minjeong K (2017). How does young womens's weight perception affect their nutrient intake?: Korean Young Women's Dietary Consumption and nutritional Deficiency Health Care for Women International. 38(11): 1247-1260. DOI:10.1080/07399-332.2017.1360300

Sharon, Bond CNM (2016). Refreshing Update on Iron Deficiency Anemia. J Midwifery Womens Health. 61: 126 126. DOI:10.1111/jmwh.124294

Sulastijah S, Sumarni DW, Helmyati S (2015). Pengaruh pendidikan gizi dalam upaya meningkatkan kepatuhan konsumsi zat besi melalui kelas ibu hamil. Jurnal Gizi Klinik Indonesia. 12(2): 79-87. DOI:10.22146/ijcn.23125.

Siah CW, Ombiga J, Adams LA, Trinder D Olynyk JK (2006). Normal iron metabolism and the pathophysiology of iron overload disorders. Clin Biochem Rev. 27(1): 5. https://www.ncbi.nlm.nih.gov/pubmed/16886043.

Susanti Tri (2018). Pengaruh dosis dan durasi pemberian tepung biji salacca terhadap kadar hemoglobin dan indeks eritrosit pada tikus model anemia 
Wijayanti et al./ Jelly Combination of Salacca Seed and Moringa Leaves Flour on Hemoglobin

(Tesis). Surakarta: Universitas Sebelas Maret Surakarta.

Silalahi V, Aritonang E, Ashar T (2016). Potensi pendidikan gizi dalam meningkatkan asupan gizi pada remaja putri yang anemia di kota Medan. KEMAS: Jurnal
Kesehatan Masyarakat. 11(2): 295-301. DOI: 10.15294/kemas.v11i1.3521

Steinbicker AU, Muckenthaler MU (2013). Out of balance systemic iron homeostasis in iron related disorders. Nurients. 5(8): 3034-3061. DOI: 10.3390/nu5083034. 